\title{
SZÜKSÉGLETEK ÉS A JOGI SZABÁLYOZÓK - AVAGY FÓKUSZBAN A CIGÁNY NEMZETISÉGI OKTATÁS
}

\author{
ORSÓS ANNA \\ Pécsi Tudományegyetem Bölcsészettudományi Kar Neveléstudományi Intézet \\ Romológia és Nevelésszociológia Tanszék
}

A tanulmány alapvetően a magyarországi cigány/roma tanulókat érintő nemzetiségi programot és annak történetiségét helyezi fókuszba. Az előrehaladott asszimiláció miatt a nemzetiségi oktatáshoz való jog érvényesülése kiemelt jelentőségű, mondhatni: nemzetiségi létkérdés. A jog, hogy nemzetiségi program szervezhető, az esélyegyenlőség elve miatt különösen fontos, még akkor is, ha önmagában kötelező erővel nem bír. A folyamatok elemzése alapján látható, hogy hazánkban a nemzetiségi oktatás szinte nemzetiségenként másként valósult meg, így különösen eltérő a cigány/roma nemzetiségi oktatás célja a kezdetektől napjainkig. A hazai cigány/roma nemzetiségi oktatás „tantárgyiasult” formáinak bemutatásán túl a tanulmány beszámol arról is, hogy ahol cigány/roma nemzetiségi oktatást folytatnak, ott jellemzően rendkívül alacsony az oktatás minősége és gyakran a cigány/roma nemzetiségi oktatás „iskolamentési stratégiák” meghatározó elemévé válik.

Kulcsszavak: cigány/roma nemzetiségi oktatás, jogi státusz, iskolamentési stratégiák, tartalomnélküliség, nemzetiségi irányelvek

The study focuses essentially on the Roma nationality programme of Hungary and its history. Due to the advanced assimilation, the enforcement of the right to nationality education is of paramount importance. It can be said that this right is the matter of existence of Roma nationality. Because of the principle of equal opportunities, the right to organize a nationality programme is particularly important, even if it is not binding in itself. Based on the analysis of several processes of national education, it turns out that in Hungary nationality education programmes are differ from each other. This paper aims to introduce the forms of Roma nationality education as school subjects. In addition, the study also reports that where Roma nationality education is provided, the quality of education is typically extremely low and Roma nationality education is often a defining element of 'school rescue strategies'.

Levelező szerző: Orsós Anna, Pécsi Tudományegyetem Bölcsészettudományi Kar Neveléstudományi Intézet, Romológia és Nevelésszociológia Tanszék, 7624 Pécs, Ifjúság útja 6. E-mail: orsos.anna@pte.hu 
Keywords: Gypsy/Roma nationality education, legal status, school rescue strategies, 'no content school subjects', nationality guidelines

\section{A cigányság státusza, oktatáspolitikai helyzete}

$\Delta$ cigány/roma nemzetiségi oktatás köznevelési helyzetét vizsgálom 1961-től napjainkig terjedő intervallumban. A téma tartalmi ismertetése előtt fontosnak tartom áttekinteni a magyarországi cigányok/romák státuszának meghatározását, majd a teljesség igénye nélkül áttekintem annak az útnak néhány fontos állomását, amely a napjainkban - egy cseppet sem problémamentes magyar nyelvü cigány/roma nemzetiségi nevelés-oktatás lehetőségéhez vezetett.

A hazai cigány/roma közösség státusza az MSZMP KB Politikai Bizottságának 1961. júniusi párthatározata óta formálisan nagy változásokon ment keresztül. Ez a párthatározat a cigányság nemzetiségként való kezelését károsnak vélte és minden olyan intézkedést, amely erre irányult, a cigányság beilleszkedését hátráltató tényezőnek tartott.

Mivel ez a párthatározat ${ }^{1}$ beilleszkedésre hívta fel a cigány/roma lakosságot, a nemzetiségi lét, az öntudat és identitás megerősítése, a cigányság kultúrájának életben tartása, nyelveik ápolása nem volt kívánatos. Az elvárt és támogatott asszimiláció pedig gyors nyelvelhagyást eredményezett a cigányság még nyelvet beszélő tagjai körében is. Ez a tény azért fontos, mert a cigányság nagyobb része hosszú generációk óta csak magyar anyanyelvü, és ennek az intézkedésnek a hatására a magukat kétnyelvünek vallók száma is tovább csökkent.

Az elmúlt időszakban a cigány/roma gyerekek oktatáspolitikai helyzetének bemutatásával tanulmányok hosszú sora (Forray-Hegedüs 1990, 1998) foglalkozott, foglalkozik azóta is, vizsgálták, vizsgálják a cigány/roma tanulók iskolai sikertelenségének okait (Réger 1995), a cigányság társadalmi, oktatási helyzetét (Forray 1995; Kertesi 1995) stb. Ezek a tanulmányok arról számolnak be, hogy - minden politikai határozat, ill. oktatáspolitikai intézkedés ellenére - a cigányság évszázados elmaradottságát a mai napig nem hozta be. Az iskolákban a lemorzsolódással leginkább veszélyeztetett tanulók, az iskolát legkorábban elhagyók többsége olyan cigány/roma fiatalok, akiknek a családi szocializációjában nincs középosztálybeli minta, e családok életének nem része az a karrierterv, amely feltételezi a kötelezőn túli iskolába járást, vagy ha mégis, az kimerül a szakmatanulásban, ritkábban az érettségit adó középiskola elvégzésében.

A cigányság helyzetét nehezíti az is, hogy az összes magyarországi nemzetiséggel, kisebbséggel ellentétben, nekik nincs anyaországuk, de társadalmi esélyeiket és más kulturális sajátosságaikat tekintve is nagyon eltérnek a többi hazai kisebbségtől, ezért az oktatáspolitika a rendszerváltásig inkább peremcsoportként definiálta és annak is kezelte a cigányságot (Forray 1998).

\footnotetext{
A forrás fellelhető a következő forráskiadványban: HAJNÁCZKY 2015.
} 
A rendszerváltás után született meg az az első önkormányzati törvény, ${ }^{2}$ amely szót ejt a nemzetiségi oktatásról és a többi nemzetiséggel egy helyen említi meg a cigányság oktatását is. Míg azonban számukra a felzárkóztató oktatást írja elő, addig a többi nemzetiség számára az anyanyelv és kultúra ápolását tartja fontosnak. Ez a fajta megkülönböztetés az 1961-es párthatározat óta nem változott, és ahogy a pártpolitika, úgy az oktatáspolitika sem tartja egyenrangúnak a cigányságot a többi nemzetiséggel, és nem vesz tudomást arról, hogy a cigányság is saját nyelvekkel és kultúrával rendelkező népcsoport.

Bár fontos, hogy ez a törvény a cigány/roma gyerekek oktatásának támogatásáról és a nemzetiségi oktatás támogatásáról egy paragrafuson belül rendelkezik, a cigányságot mint etnikumot ismeri el, és az ő esetükben a többi nemzetiséggel ellentétben, a felzárkóztatást és az óvodai, valamint a bukásmentes iskolai előrehaladásuk biztosításához szükséges többletfoglalkozást írja elő (Forray 1998).

Az 1993-as kisebbségi törvény már elnevezésében is mutatja a különbséget a kisebbségek megítélésében, itt ugyanis a cigányság mint etnikai kisebbség jelenik meg a többi nemzeti kisebbség mellett.

$\mathrm{Ez}$ a törvény mégis nagyon fontos, ugyanis az addig homogén közösségként számon tartott cigányság ettől a törvénytől válik nyelvi szempontból legitim módon is heterogénné, hisz a törvény ${ }^{3} 42$. $\S$-a a hazai cigányság által használt két nyelvet ekkor ismeri el és nevezi meg elsőként. „E törvény értelmében kisebbségek által használt nyelvnek számít a bolgár, a cigány (romani, illetve beás), a görög, a horvát, a lengyel, a német, az örmény, a román, a ruszin, a szerb, a szlovák, a szlovén és az ukrán nyelv."

A kisebbségi oktatás tartalma ugyan változott az ezt követő években, a cigányok státusza azonban 2011-ig változatlan maradt.

A 2011. évi CLXXIX., a nemzetiségek jogairól szóló törvény ${ }^{4}$ hatálybalépése miatt megszűnik a nemzeti, illetve az etnikai kisebbség fogalma, helyükbe egységesen a nemzetiség kifejezés lép. Eszerint nemzetiségnek minősül: a bolgár, a görög, a horvát, a lengyel, a német, az örmény, a roma, a román, a ruszin, a szerb, a szlovák, a szlovén és az ukrán. E törvény értelmében „22. $\$(1)$ nemzetiségek által használt nyelvnek számít a bolgár, a görög, a horvát, a lengyel, a német, az örmény, a cigány (romani, illetve beás, a továbbiakban együtt: roma), a román, a ruszin, a szerb, a szlovák, a szlovén és az ukrán nyelv, továbbá a roma és az örmény nemzetiség esetében a magyar nyelv is. (2) Az állam a magyarországi nemzetiségek anyanyelvét közösség-összetartó tényezöként ismeri el. Tekintet nélkül arra, hogy a köznevelési intézménynek ki a fenntartója, támogatja a nemzetiségek által használt nyelv alkalmazását a nemzetiségi köznevelésben. A nemzetiségi köznevelés többletköltségét - jogszabályban meghatározott módon - az állam viseli." (5.\$(1)).

A nemzetiségi nevelés-oktatás szabályait így tehát valamennyi nemzetiség - köztük a cigányok/romák - esetében is egységes jogszabályi feltételek határozzák meg.

Látható, hogy minden szabályozás ellenére a magyar oktatási rendszerben a hazai cigány/roma közösség státuszában sem volt soha egyenrangú a többi hazai nemzetiséggel, a cigány/roma nemzetiségi oktatás tartalmát sem tartotta az oktatáspolitika soha

1990. évi LXV. törvény a helyi önkormányzatokról.https://mkogy.jogtar.hu/jogszabaly?docid=99300077. TV.

3 1993. évi LXXVII. törvény a nemzeti és etnikai kisebbségek jogairól. https://mkogy.jogtar.hu/ jogszabaly?docid=99300077.TV.

4 2011. évi CLXXIX. törvény a nemzetiségek jogairól. https://mkogy.jogtar.hu/jogszabaly?docid= a1100179.TV. 
egyenrangúnak más hazai nemzetiség oktatásához hasonlóan. A magyar oktatási rendszerben a kezdetektől benne gyökerezik a megkülönböztetés, a legkülönbözőbb formákban megnyilvánuló diszkrimináció.

\section{A kisebbségi/nemzetiségi oktatás tartalma, szervezési körülményei}

A továbbiakban azt tekintem át - a teljesség igénye nélkül -, hogy a cigány/roma tanulók oktatásának fókusza miként változott az 1961-es párthatározattól napjainkig.

Az előző részben hivatkozott párthatározat hatására a cigány/roma gyermekek oktatási helyzete látványosan megváltozott, javulni kezdett. A határozat a cigány lakosság helyzetéről és annak megjavításával kapcsolatos feladatokról is rendelkezett, amelyek között az alábbi intézkedések is szerepeltek. „Külön figyelmet kell forditani az iskoláskorú cigánygyermekek nevelésére és oktatására. Törekedni kell arra, hogy mind több cigány fiatal nyerjen szakképzettséget. [...] Küzdeni kell az írástudatlanság ellen, emelni kell a felnött cigánylakosság kulturális színvonalát. Be kell vonni öket a társadalom politikai és kulturális életébe." (Hajnáczky 2013).

Ez a párthatározat számos szempontból kiemelkedő jelentőséggel bír, hisz egyrészt az ezt megelőző időszakból származó kevés forrásanyagok egyik fontos kordokumentumává vált, másrészt olyan intézkedéssorozatot indított el, amely a cigányság életében addig sosem tapasztalt változásokat idézett elö.

Sokak által a mai napig vitatott kérdés, hogy ezek a változások a teljes cigányság helyzetét pozitív irányba terelték-e, hisz az azóta eltelt sok évtized sem oldotta meg azokat a problémákat, amelyek akkor is napirenden voltak: a telepfelszámolás a mai napig nem zárult le, a cigány/roma tanulók iskolai helyzete, a cigány/roma népesség iskolázottsági állapota - bár az eltelt évtizedek alatt sokat fejlődött - nem vált jobbá, helyzetük e tekintetben továbbra sem megnyugtató.

Ebben az időszakban a cigányság megítélése során az etnikai és a szociális kérdés rendre összekeveredik, és ugyanezek a kérdések vetődnek fel később a cigányság kultúráját illetően (Szubay 1999). Évtizedekig alapvetően a cigányság „átnevelése” volt a cél, az általuk beszélt nyelvek, kultúrájuk fenntartásához, a közösség kulturális autonómiájának megőrzéséhez az egyetemes emberi jogok alapján bármennyire is lett volna joguk, lehetőségük nem adódott.

A 1961-es párthatározatot követően számottevő mértékben nőtt a cigány/roma gyermekek beiskolázása, többen jutottak el az általános iskola felső tagozatába. Ugyanakkor az általános iskola nyolc osztályát csak töredékük végezte el, szakmunkásképzőbe pedig alig-alig kerültek be (Hajnáczky 2015). Ahogy azonban a cigány/roma tanulók száma nőtt az általános iskolai oktatásban, úgy nőtt a kisegítő iskolába irányított tanulók száma is. Az otthonról hozott hátrányaik miatt gyakran nyilvánították őket enyhén értelmi fogyatékosnak, így kisegítő osztályok létrehozásával próbálták megoldani e tanulók hátrányos helyzetét.

A kisebbségi oktatáshoz való jogot, a nemzeti és etnikai kisebbségek jogairól szóló 1993. évi LXXVII. törvény fogalmazza meg elsőként mint egyéni és közösségi jog. Eszerint a kisebbséghez tartozó személynek joga van részt venni anyanyelvű oktatásban, a közösségnek pedig joga van, hogy kisebbségi óvodai nevelés, kisebbségi alap- és középfokú nevelés és oktatás, továbbá felsőfokú képzés, illetve a kisebbségi 
önkormányzatok segítségével (együttműködve a helyi önkormányzatokkal) a feltételek megteremtését kezdeményezze.

Az ekkor hatályba lépő közoktatási törvény megerősítve a kisebbségi törvényben foglaltakat, lehetővé teszi, hogy a hazai nemzeti vagy etnikai kisebbségek (ez utóbbi jelző köztudottan a cigányokra/romákra vonatkozott) gyermekei - a szülők kezdeményezése alapján - óvodai és iskolai nevelésben részesülhessenek saját anyanyelvükön vagy magyarul, de akár anyanyelvükön és magyarul is.

Azonban a cigány/roma tanulók esetében speciális feltételek kialakítását tette lehetővé a kisebbségekről szóló törvény, s bár ennek és a közoktatási törvénynek az ellentmondásosságát sokan vizsgálták (Szüdi 1996), a hazai legnagyobb kisebbség esetében „cigány felzárkóztató programok” valósulnak meg, amelyek döntően tantárgyi korrepetálásokat jelentenek, és messze nem illenek a nemzetiségi oktatás logikájába.

A kilencvenes évek oktatáspolitikájának nem sikerült megoldania a hátrányos helyzetű cigány/roma gyermekek iskolai előmenetelének segítését a kisebbségi oktatással, ugyanakkor törvényes lehetőséget biztosított ahhoz, hogy ezeket a gyermekeket külön osztályba, csoportba sorolják, szegregáltan oktassák. Az új jogszabály elsősorban ezt törekedett megakadályozni.

Az 1990-es évek első felében a cigány/roma tanulók oktatásának alapfokon nincs elkülönült kisebbségi intézményrendszere, középfokon is csak néhány cigány kisebbségi pedagógiai program alapján oktató intézmény létezik (például a pécsi Gandhi Gimnázium és Kollégium). A cigány kisebbségi oktatás megszervezését - a többi kisebbségi oktatási formához hasonlóan - a szülőknek kell írásban kezdeményezniük. Enélkül elkülönített cigány osztály vagy csoport mủködtetése a cigány/roma tanulók hátrányos megkülönböztetését eredményezi. Előzményként fontos megemlíteni A nemzeti, etnikai kisebbség óvodai nevelésének irányelve és a nemzeti etnikai kisebbség iskolai oktatásának irányelve kiadásáról szóló - többször módosított - 32/1997. (XI. 5.) MKM rendeletet, mely - a 2003-ban történt tartalmi változtatásig - oktatásszervezési keretként a külön csoportban történő oktatást határozta meg.

Több szakértő és a kisebbségi ombudsman is kifogásolta a „cigány felzárkóztató oktatás" elnevezést, mivel az a cigányságot felzárkóztatandó közösségként határozza meg (Kaltenbach 2003). Az Oktatási Minisztérium 13/1999. (III. 8.) OM rendeletében - a szabályozás tartalmának változatlanul hagyása mellett - új nevet adott az oktatási formának, a cigány kisebbségi oktatást.

A cigány kisebbségi oktatási programnak két elemet kellett tartalmaznia: egyrészt a kisebbségi önismeret fejlesztését, a kulturális és nyelvi nevelést, másrészt a hátrányok csökkentését célzó szocializációs, kommunikációs, tantárgyi fejlesztést, tehetséggondozást. Vagyis a cigány kisebbségi oktatás az elmaradottság értékítéletét füzi a cigány/ roma identitáshoz (Forray-Hegedüs 1995).

2003-ban a közoktatási törvény után változott a nemzetiségi oktatás irányelve is: a cigány nemzetiségi oktatás részből kikerült minden olyan elem, mely a szociális hát= rányokra utaló felzárkóztatást célozta. Így az 58/2002. OM rendelet szerint külön normatívát igényelhettek az iskolák a cigány népismeret, valamint bármelyik cigány nyelv oktatására. Azaz 2003-tól a romani vagy beás nyelv oktatását a 32/1997. MKM rendeletnek a - Magyar Közlönyben megjelent - 2002/147. módosítása teszi lehetővé. A módosítás szerint az óraszám heti kettőre csökken, így könnyebbé válik az összevonás 
(blokkosítás) az év során, s vendégtanárral, tábor vagy más rendezvény keretében szervezhető a nyelvoktatás.

$\mathrm{Ez}$ az intézkedés, bár oktatáspolitikai szempontból fontos, nyelvpolitikai szempontból több veszélyt jelentett. A rendelet segítségével a nyelvoktatás feltételei nem teremtődtek meg, a cigány nyelvek esetében ez a megengedő jellegủ rendeletmódosítás a cigány nyelvek tekintélyét a többi kisebbségi nyelvhez képest nem emelte.

A 2003-as törvénymódosítás igyekezett visszaszorítani a szegregációt, emellett kötelezővé tett olyan eljárásokat, amelyek a hátrányos helyzetü, különösen a cigány/roma gyermekek egyenrangú beilleszkedését célozták. Az óvodáztatás kiterjesztése, a kezdő évfolyamokon az évismétlés tiltása, a szakiskolai hálózat modernizációja, a cigány/roma és hátrányos helyzetű gyermekek integrációja és deszegregációja, valamint a sajátos nevelési igényü gyermekek integrációja voltak a kiemelt célok. A képesség kibontakoztatása tanulóközösségben, az eredeti csoporton belül zajlik (57/2002-es OM rendelet), a differenciáló pedagógiában gondolkodik. Háromszoros normatívával támogatja a hátrányos helyzetű és a többiek tényleges együttnevelését, heterogén tanulócsoportok létrehozását, fenntartását és az ehhez szükséges módszertan meghonosítását - ösztönözve a pedagógiai kultúra fejlődését (Arató-Varga 2005).

A rendelet szerint a részt vevő tanulók nevelése és oktatása, tudásának értékelése ún. integrációs pedagógiai rendszer (IPR) alkalmazásával történt. A pedagógiai rendszer részét képezte a tanterv, a ráépülő tanítást-tanulást segítő és értékelő eszközrendszer, a gyakorlati alkalmazást lehetővé tevő akkreditált pedagógusképzési és továbbképzési kínálat, valamint a pedagógiai szakmai szolgáltató tevékenység. Az új fejlesztések figyelemmel kísérésére, a tevékenység összehangolására hivatalt hoztak létre, Országos Oktatási Integrációs Hálózatot (OOIH).

$\mathrm{Az}$ OOIH 2003 első felében négy régióban (Dél-Dunántúl, Észak-Magyarország, Észak-Alföld, Közép-Magyarország) nyílt pályázat útján 45 általános iskolát („bázisintézményt") választottak ki, amelyek mellé az integrációs program fejlesztését segítő tanácsadó, illetve kistérségi koordinátor került. A bázisintézmények modellként szolgáltak a hálózathoz újonnan csatlakozó iskolák számára, s ezek látták el az épülő Országos Oktatási Integrációs Hálózat multiplikátori funkcióját.

A törvénymódosítás elválasztotta a szociális hátrányokból adódó lemaradások iskolai pótlását a kisebbségi jogok iskolai keretben történő biztosításától. Mindkét esetben a szülöknek kell nyilatkozniuk arról, hogy gyermekük számára mely szolgáltatás(ok)at igénylik az iskolától, amelyekhez az iskolák többlettámogatást kaptak. 2004 januárjától a képességkibontakoztató normatíva összege tanulónként 20 ezer, az integrációs normatíváé 60 ezer forint.

A közoktatásról szóló 1993. évi törvény 58/2002. OM rendelete ily módon lehetővé tette, hogy a magyar nyelvű kisebbségi népismeret oktatása elkülönüljön a kisebbségi nyelvoktatástól. Külön normatíva igénylését tette lehetővé a nevelési-oktatási intézmények számára a cigányság identitásának erősítése szempontjából, a cigány népismeret (22 ezer forint kisebbségi normatíváért), valamint ugyanennyi forint bármelyik cigány nyelv (romani/beás) oktatása esetén tanulónként.

Mivel a fenntartó önkormányzatok képviselő-testületei határoznak a kiegészítő normatívák igénybevételéről, előfordult, hogy az iskola vezetése kész lett volna integrált pedagógiai program indítására, a képviselők a többséghez tartozó gyermekek érdekeinek védelmében nem szavazták meg. Bár létrehoztak olyan hivatalokat, amelyek 
koordinálják a közpénz fenti céloknak megfelelő elosztását, nem rendelkezünk - maga a fenntartó minisztérium sem - információkkal az egyes iskolákban zajló tevékenységekről, a támogatások hasznosulásának ellenőrzése is korlátozott volt. Azaz nincs semmilyen támpont arra, ami alapján nyomon követhető lenne, mennyire voltak sikeresek a cigány/roma gyerekekre is irányuló programok, hogy az iskolák milyen mértékben voltak jogosultak integrációs normatíva igénybevételére, vagy hogy amennyiben jogosultak lettek volna, miért nem vették igénybe e forrásokat.

2003-tól a nemzetiségi és cigány kisebbségi oktatást folytató közoktatási intézményekben a legváltozatosabb formában valósul meg a nemzetiségi oktatás. Az iskolák egy részében többtípusú oktatás, illetve több nyelv különböző típusú oktatása is folyt. Emellett előfordult, hogy az iskola a nemzetiségi nyelvoktatás mellett cigány kulturális kisebbségi nevelést is folytatott valamelyik cigány nyelv oktatásával vagy annak oktatása nélkül.

A kisebbségi nyelvoktatás és népismeret-tanítás megszervezéséhez nyolc tanuló és szülő írásbeli kérése után foghat az iskola. Ez az oktatás minőségileg más, mint más tantárgyaké. Feladat- és célmeghatározásában ugyanis nemcsak a puszta idegennyelvtudás, hanem kisebbségi történelem, kultúra, hagyományőrzés, népismeret, önismeret is szerepel, ami segíti a kisebbséghez tartozót abban, hogy megtalálja, megőrizze és fejlessze identitását, erősítse a közösséghez való kötődést. Ha egy intézmény több (óvoda, általános iskola, gimnázium, kollégium stb.) közoktatási feladatot is ellát, akkor értelemszerüen, a kisebbségi nevelés és az adott intézmény általános célkitüzésein túl, a szülőt a ténylegesen igényelt szolgáltatásról is tájékoztatnia kell, vagyis arról, hogy a konkrét kisebbségi nevelési, nevelési-oktatási forma keretei között mi az intézmény célja és feladata.

A kisebbségi nyelv és kultúra ápolása, bármennyire is fontos szimbólumai a kulturális identitásnak, a magyarországi cigányok/romák esetében folyamatosan csorbát szenvednek.

Miközben a Kárpát-medencében mára eltérő mértékben, fokozatosan megteremtődtek a lehetőségek a kisebbségi nyelvek intézményes színtereken való használatára, addig mind a romani, mind a beás nyelvet beszélő közösségek jó része a nyelvcserét, a magyar nyelvi egynyelvűségben végződő folyamat különböző fázisait éli át. A cigányok nyelvhasználatára - ahogy a többi magyarországi kisebbségekére is - az erőteljes nyelvi asszimiláció jellemző. Ennek eredményeképp, bár kisebbségenként eltérő arányban, de többen vallják anyanyelvüknek a magyart, mint a nemzetiségi nyelvet, pedig a nemzetiségi hovatartozás reprezentációjában, a kisebbségi identitás, illetve a kisebbségi csoport kohéziójának megőrzésében különösen nagy jelentősége van az anyanyelvnek. A nyelv a nemzetiségi hovatartozás legfőbb ismertetőjegye, gyakran a csoporttal való azonosítás egyik legfontosabb eszköze.

A nemzeti és etnikai kisebbségek jogairól szóló törvény ugyan jogot és lehetőséget ad meghatározott nemzetiségi intézmények létrehozására és ilyen típusú oktatás és nevelés folytatására, a kisebbségi oktatás keretében a nyelv és népismeret oktatására, ám a feltételek biztosítása esetében minden esetben jelentős hiányokat láthatunk.

A cigány kisebbség óvodai, illetve iskolai nevelésének, oktatásának formáit, tartalmi kereteit a Nemzeti, etnikai kisebbség óvodai nevelésének irányelvéról és a Nemzeti, etnikai kisebbség iskolai oktatásának irányelvéről szóló rendeletek szabályozzák. Az óvodai nevelés célja, hogy oly módon készítse fel a gyermekeket a sikeres iskolai elö- 
menetelre, hogy tudatosan építsen a cigány kultúra és a többségi kultúra közötti különbözőségekre és hasonlóságokra. Új elem, hogy az Országos Roma Önkormányzatnak, illetve a cigány kisebbségi önkormányzatoknak - a kulturális-oktatási autonómia jegyében - iskolafenntartási és -alapítási jogaik vannak, saját iskolákat működtetnek. $\mathrm{A} z$ iskolai oktatás-nevelés biztosítja a cigány tanulók számára a cigányság kulturális értékeinek megismerését, a cigányság helyzetéről, jogairól, szervezeteiről és intézményeiről szóló ismeretek oktatását (MNTF Stratégia 2011).

Magyarországon a cigány kisebbségi nevelésnek 2003-tól alapvetően két formája müködött.

1. Cigány kulturális kisebbségi nevelés-oktatás romani vagy beás nyelv oktatásával.

2. Cigány kulturális kisebbségi nevelés-oktatás magyar nyelven, romani vagy beás nyelv oktatása nélkül (Jelentés 2011).

A 2005-től folyamatosan végzett vizsgálatok, a romani és/vagy beás nyelvet is oktató cigány kisebbségi programokat müködtető intézmények körében adnak információkat e programok működéséről, hatékonyságáról, és adatokkal szolgálnak azokról az intézményekről, amelyekben a cigány kisebbségi nevelés fent említett formáiból a nyelvek oktatása is megvalósul.

A kutatás eredményei igazolják, hogy a közoktatási törvény más alkalmazási feltételeket támaszt, ha idegennyelv oktatásáról, és mást, ha nemzetiségi nyelvről van szó. A z alkalmazási feltétel nyelvpolitikai szempontból jelentős, hisz lehetőséget teremt a kisebbségi nyelv bevezetésére a köznevelésbe, ám szakmai szempontból eleve kudarcra ítélt ez a vállalkozás a csupán nyelvi kompetenciával rendelkező egyén számára - pedagógiai és nyelvtanári végzettség hiányában.

A 2011. évi CXC. törvény a nemzeti köznevelésről (3. melléklet) - amely különbségtétel nélkül minden nemzetiség számára előírja a nemzetiségi iskolai nevelés-oktatás 5-12. évfolyamán a nemzetiségi nyelvtanár alkalmazását - sem oldja meg a problémát, mivel az ilyen szakemberek képzése hiányt mutat. A nemzetiségi normatívát igénylő iskolák, mivel szakképzett nyelvtanáraik nincsenek, nagyon változatos, ám hosszú távon nem biztosítható, és a hatályos jogszabályoknak ellentmondó módon próbálják a nyelvoktatást megoldani.

Az oktatás feltételeit vizsgálva a kisebbségi oktatást folytató intézmények vezetőivel, illetve nyelvet oktatóival szemben emiatt a törvény megengedő, és elegendő, ha az oktató az adott nyelvböl legalább középfokú „komplex” típusú államilag elismert nyelvvizsga-bizonyitvánnyal vagy azzal egyenértékü okirattal rendelkezik (MK11-162: 2011: 69).

A cigányok az új köznevelési koncepcióban 2011-töl nemzetiségként jelennek meg, utalva a 1993 óta érvényben lévő kisebbségi törvényre, mely a nemzetiségiekkel egyenlő szintre emeli az etnikai kisebbségeket, megerősítendő, hogy a magyarországi cigányok iskolázása a nemzetiségi oktatással azonos támogatási rendbe került. A törvény a nevelési-oktatási intézményekben pedagógus munkakörben alkalmazottak végzettségi és szakképzettségi követelményeiről szóló részében is nemzetiségi nyelvtanár végzettséghez köti a nyelvoktatást, de a képzésben változás nem történt (MK11-162: 2011:73).

A törvény készítői arról a tényről sem vettek tudomást, hogy épp ezt a hiányt kívánja orvosolni a már több mint két évtizede létező romológusképzés. A felsőoktatásban minden évben végeznek olyan szakképzett romológusok, akik a cigány nyelvek és a népismeret képzéséhez tanárként egyetemi végzettséget szereznek, és a kisebbségi nyelv és 
kultúra ápolása területén is rendelkeznek olyan kompetenciákkal, melyek a köznevelésben hasznosíthatóak lennének.

A cigány/roma nemzetiségi oktatáshoz szükséges végzettség biztosítása máig megoldatlan probléma. Érthetetlen, hogy a köznevelési és a felsőoktatási törvény miért nem tartalmaz szándékot és garanciát arra, hogy nemzetiségi nyelvoktatást folytató intézmények tanárai számára előírja a szükséges romológiatanári végzettség megszerzését. Ezt az egyre több oktatási problémát és egyenlőtlen esélyeket teremtő helyzetet az oktatáspolitika a mai napig nem orvosolta.

A nemzetiségi nevelés-oktatás szabályait valamennyi nemzetiség, köztük a cigányok/ romák esetében is egységes jogszabályi feltételek határozzák meg. Megszervezésének kezdeményezése, az abban való részvétel a szülők írásos igénye alapján valósul meg, az időkeretét, tartalmát meghatározó jogszabályok (irányelv, kerettantervek) az országos nemzetiségi önkormányzatok egyetértésével kerültek kiadásra. A nemzetiségi nevelést, oktatást az irányelvben meghatározottak szerint kell folytatni, a nemzetiségi kerettantervek alkalmazása is kötelező. A nemzetiségi nevelés-oktatás az adott nemzetiség nyelvének, kultúrájának, hagyományainak átörökítéséről szól. Legalább nyolc, azonos nemzetiséghez tartozó szülő írásos kérelmére kötelező megszervezni, az intézmény vezetőjének ebben nincs mérlegelési joga.

A nemzetiség óvodai nevelésének irányelve és a nemzetiség iskolai oktatásának irányelve kiadásáról szóló 17/2013. (III. 1.) EMMI rendelet (a továbbiakban: nemzetiségi irányelv) tartalmazza (nem teljeskörüen) valamennyi nemzetiség, valamennyi oktatási formára kiterjedő részletes fejlesztési feladatait.

E rendelet mellékleteként kiadott Nemzeti alaptanterv (a továbbiakban: NAT) rendelkezései határozzák meg az érvényes értékeket, műveltségképet, tudás- és tanulásértelmezést.

A magyarországi cigány/roma nemzetiségre vonatkozóan a NAT-ban ez áll: „A NAT fontos szerepet szán az egyetemes magyar nemzeti hagyománynak, a nemzeti öntudat fejlesztésének, beleértve a magyarországi nemzetiségekhez tartozók öntudatának ápolását is. Ebböl következöen a nemzetiségekre vonatkozó tudástartalmak föbb tartalmi jellemzöi (illeszkedve a regionális és lokális sajátosságokhoz) a tartalmi szabályozás különbözö szintjein, illetve az iskoláztatás minden szakaszában arányosan meg kell, hogy jelenjenek."

A NAT-ban megfogalmazott elvek, célok, fejlesztési feladatok és müveltségi tartalmak a képzési szakasz sajátosságai szerint több változatban is kimunkált dokumentumokban, a kerettantervekben öltenek testet, amelyek egyben a NAT és helyi tanterv között közvetítő, szabályozó, korlátozó funkciót látnak el.

Jelenleg a magyarországi iskolák elfogadott pedagógiai programok szerint müködnek, amelyeknek egyik legfontosabb eleme a helyi tanterv. A helyi tantervek a NAT-ra épülnek, az Oktatási Minisztérium által készíttetett kerettantervek pedig köztes szabályozóként lépnek be a NAT és a helyi tantervek közé.

\section{A cigány/roma nemzetiségi nevelés, oktatás megvalósulása napjainkban}

Magyarországon a nemzetiségi nevelés, oktatás két tantárgy keretei között, a beás és/ vagy romani nyelv és a népismeret oktatása során valósul meg. A 2015-ben végzett kutatásunk szerint a romani és/vagy beás nyelvet oktató köznevelési intézmények száma 
nem érte el a harmincat, míg cigány/roma nemzetiségi népismeretet 383 intézményben tanítottak (Orsós 2015).

A cigány/roma népismeret oktatása magyar nyelvű, tekintettel arra, hogy a magyarországi cigányság jelentős része egykori anyanyelvét már sok nemzedékkel ezelőtt elfelejtette. Problémát ez esetben a cigány kultúra hiányos ismerete jelent, hisz a nemzeti alaptantervnek nem volt része a romológiai ismeretek átadása, a tanárképzés alapozó kurzusainak sok felsőoktatási intézményben pedig ma sem az.

A Nemzetiségi nevelés-oktatás kereteit, feladatait a 17/2013. (III. 1.) EMMI rendelet a nemzetiség óvodai nevelésének irányelve és a nemzetiség iskolai oktatásának irányelve jelöli ki.

Általános rendelkezések 4. A nemzetiségi nyelv és irodalom, valamint a nemzetiségi népismeret oktatásához szükséges idökeret biztositásáról szól.

Amennyiben legalább nyolc, azonos nemzetiséghez tartozó szülő azt kezdeményezi, a nemzetiségi óvodai nevelést, nemzetiségi iskolai nevelés-oktatást a kérelem beérkezését követő naptári évben kezdődő nevelési évtől, tanévtől felmenő rendszerben meg kell szervezni, feltéve, hogy legalább nyolc gyermek, tanuló valóban be is iratkozik az óvodába, iskolába.

A nemzetiségi nevelés-oktatást a következő oktatási formák szerint lehet megszervezni:

a) anyanyelvü nevelés-oktatás,

b) kétnyelvű nemzetiségi nevelés-oktatás,

c) nyelvoktató nemzetiségi nevelés-oktatás,

d) magyar nyelvű cigány/roma nemzetiségi nevelés-oktatás,

e) kiegészítő nemzetiségi nevelés-oktatás.

A fent idézett rendelet (5) §-ának az (1) bekezdés d) pontja szerinti nevelés-oktatás a) biztosítja a a romák, a cigányság kulturális értékeinek megismerését, a romák/ cigányok történelméről, irodalmáról, képzőművészetéről, zenei és tánckultúrájáról, valamint hagyományairól szóló ismeretek oktatását, és b) a legalább heti egy tanórára kiterjedő kötelező cigány/roma népismeret oktatása mellett heti legalább két tanórának megfelelő idő keretében cigány/roma kulturális tevékenységet is biztosít.

A célok teljes körü megvalósulását nehezíti, hogy bár a valóságban a nemzetiségi nevelésben, oktatásban való részvétel nem alanyi és másokat kizáró jog, az Alaptörvény formálisan is lehetővé teszi, hogy a nemzetiséghez tartozókkal egy sorban a nemzetiséghez nem tartozók is a nemzetiségi pedagógiai program szerint tanuljanak, mégis a korábbi szabályozást érdemben megismételve - továbbra is kifejezetten a Magyarországon élő nemzetiségek (alanyi) jogaként jelöli meg az anyanyelvű oktatáshoz való jogot.

A cigány/roma nemzetiségi oktatást folytató intézmények körében végzett vizsgálat (Orsós 2015) azt mutatta, hogy a cigány nemzetiségi oktatást sok esetben nem a cigány szülők kezdeményezésére és kérésére szervezték meg, hanem az intézményi és/vagy a nem cigány szülők érdekei alapján, gyakran valódi tartalom nélkül.

A vizsgálat során kiderült, hogy a cigány/roma nemzetiségi oktatást folytató intézmények többségében - a szükséges személyi és tárgyi feltételrendszer hiányosságai miatt - jellemzően rendkívül alacsony az oktatás minősége és a spontán módon létrejött szegregáció „legalizálására” is alkalmas. „A nemzetiségi oktatás választásának szabadsága lehetővé teszi ugyanis, hogy a nemzetiségi oktatás sajátos szelekciós mecha- 
nizmusként is működjön, a cigány tanulóktól »abszolúte jogszerűen « különíthessék el a nem cigány (és nemzetiségi oktatást igénylő) tanulókat. Leválik a cigány és a hátrányos helyzetű tanulókról (a kettő között nagy az átfedés) a nemzetiségi hovatartozású tanuló, de leválhat/elkülönülhet az is, aki a nemzetiségi oktatást csak az idegennyelv-tanulási lehetőség miatt választja." (Fórika 2013)

A 2012-es évi jogszabályi változások alapján már nem jár kiegészítő normatíva a nemzetiségi oktatáshoz - feladatfinanszírozás valósul meg -, így a cigány, roma nemzetiségi oktatás iránti „szülői igény” is visszaesett, ám a nemzetiségi oktatást folytató intézmények száma mégsem csökkent jelentősen. Különösen kistelepüléseken - de nem csak ott - gyakran fontolóra veszik a nemzetiségi oktatás bevezetését azon hosszú távú érdek alapján, hogy a nemzetiségi oktatásban részt vevő iskoláknál az osztályindítás már 8 fővel lehetséges, míg a nem nemzetiségi oktatást folytató intézmények esetében minimum 15 tanuló szükséges az első osztály elindításához, hogy az adott iskola ne váljon tagiskolává.

„Az ombudsmani esetgyakorlatokból az derül ki, hogy a cigány szülők gyakran akkor kérik a cigány, esetleg más nemzetiségi oktatást gyermekük számára, ad abszurdum más nemzetiségi oktatásra térnek át vagy igénylésüket visszavonják, ha az intézmény érdekei úgy kívánják." (Fórika 2015) Így az oktatási forma bevezetésének motivációjában alkalmanként a szülői igény is kétségbe vonható, a létszámadatok ugyanis azt mutatják, hogy az igénylést helyenként főként az intézményi érdek határozza meg.

A 2015-ben vizsgált intézmények között nem egy olyan található, amelyben a cigány/ roma nemzetiségi nevelésnek, oktatásnak nincs tartalma, a feladattal megbízott pedagógusok nem rendelkeznek azzal a tudással és azokkal a tárgyi feltételekkel, amelyek szükségesek lennének e tantárgyak oktatásához.

A kutatás során igazolódott, hogy a cigány/roma nemzetiségi oktatás esetében hazánkban nem valósul meg a minőségi oktatáshoz való hozzáférés: a rendszerszintü hátrányok (a nem megfelelő vagy hiányos nemzetiségi tanárképzés, személyi, tárgyi feltételek egyenetlensége) hozzájárulnak ahhoz, hogy kimondható legyen: a cigány/ roma nemzetiségi nevelésnek, oktatásnak a feltételei sem a köznevelés, közoktatás, sem a felsőoktatás szintjén nem teremtődtek meg még kielégítő módon, ezért a nemzetiségi nevelés, oktatás céljainak megvalósulása is részleges.

A felzárkózási stratégia kifejti: „A minőségi oktatáshoz történő hozzáférés problémája a halmozottan hátrányos helyzetű tanulókat érinti, azon belül is még erőteljesebben a roma tanulókat. Ennek az egyik oka az, hogy a roma gyerekek csoportja erősen felülreprezentált a halmozottan hátrányos helyzetűek között. Néhány kutató szerint (Kertesi-Kézdi 2010) a halmozottan hátrányos helyzetű gyerekek nagyjából fele cigány/ roma, és a cigány/roma tanulók majdnem kétharmada halmozottan hátrányos helyzetü. A cigány/roma nemzetiségi oktatás ezért gyakran ott szerveződik, ahol a halmozottan hátrányos helyzetű tanulók koncentrálódnak. Ez rendszerint együtt jár a pedagógiainevelési gondok összesűrűsödésével, ami még a legfelkészültebb tanárok számára is kihívást jelent. A szegregációval szinte törvényszerűen együtt járó tanári kontraszelekció miatt a feladat alkalmanként leküzdhetetlen, a mindennapi tanítási-tanulási folyamat pedig frusztrációt jelent a pedagógusnak és a tanulónak egyaránt.

A cigány/roma nemzetiségi oktatást folytató intézmények kompetenciamérési adatait vizsgálva az eredmények következetesen és kifejezetten gyengék (Balázsi et al. 2012). 
Ha mindehhez hozzátesszük, hogy a cigány/roma nemzetiségi oktatás viszonylag sok intézményben folyik, miközben az oktatás személyi és tárgyi feltételei szinte teljesen hiányoznak, egyértelmü, hogy a cigány/roma nemzetiségi oktatás gyakorlata ebben a formájában nem erősíti az esélyteremtést, nem szolgálja a társadalmi felzárkózást és nem járul hozzá a társadalmi különbségek csökkenéséhez sem.

A 2020-ban módosult és a napokban bevezetésre kerülő NAT és a nemzetiségi nevelést, oktatást meghatározó nemzetiségi irányelvek - az előzetesen hangoztatott álláspont ellenére, miszerint a NAT nem változik erőteljesen, a nemzetiségi irányelvek pedig változatlan formában maradnak - igen jelentős változást mutatnak. A két idézett dokumentumban lévő ellentmondások a megvalósítást szabályozó rendelet hiányában jelenleg feloldhatatlanok: A NAT ugyanis nem tartalmazza azt az egyórás időkeretet, amely a cigány/roma népismeret önálló tárgyként való tanítását biztosítaná. Az irányelvek újdonsága, hogy lehetőséget adnak a népismeret integrált oktatására is anélkül, hogy ennek a legminimálisabb feltételei is meglennének. Ez az önálló tantárgy megszünését jelentheti.

„A nemzetiségi népismeret feldolgozására előírt óraszám 1-12. osztályig heti 1 óra, mely intézményi döntés alapján a szabadon tervezhető időkeret illetve az élő idegen nyelvre rendelkezésre álló időkeretéből átcsoportosítható vagy egyéb tárgyak tananyagába integrálható. $\mathrm{A} z$ intézmény helyi tantervének részletesen tartalmaznia kell az integrálás tantárgyait, módját. A nemzetiségi népismeret tantárgy szervezése részben megvalósulhat projektnapok, témahét vagy tematikus hét keretében, továbbá tömbösítve is." (Nemzetiségi irányelvek 2020)

A bizonytalanságot és az értelmezhetetlenséget az okozza, hogy a törvényi módosítás végrehajtását szabályozó rendelet augusztus utolsó napján még nem jelent meg. Ennek hiánya a magyar nyelvű cigány/roma nemzetiségi nevelés-oktatást folytató intézmények vezetőinek azért jelent nagy gondot, mert bár a népismerethez az önálló órát a szabadon felhasználható órakeretből tudnák biztosítani, ám a nemzetiségi irányelvek a szabadon tervezhető időkeret felhasználásáról is rendelkeznek, így ezek figyelembevétele után már nem marad idő a népismeret óra önálló tárgyként való oktatására.

A megjelenésre váró rendelet még oldhat ezen az ellentmondáson, de mivel ennek megjelenése már csak a tanév elkezdése után várható, a tantárgyfelosztás és az órarend a köznevelési intézményekben elkészültek, így e tantárgyat már csak a következő tanévtől tudják szabályosan megtervezni, ha a rendelet ezt egyáltalán lehetővé teszi.

\section{Összegzés}

A cigány/roma nemzetiségi népismeret tantárgy integrált oktathatósága a feltételek hiányossága miatt visszalépést jelent az eddigi helyzethez képest is.

Az Oktatáskutató és Fejlesztő Intézet 2015-ben egy kiemelt projekt keretében „A roma kultúra reprezentációja a tartalomszabályozók, tartalomhordozók körében, valamint ezek fejlesztési lehetőségei" címmel azt vizsgálta, hogy a hatályban lévő tartalmi szabályozókban és a gyakorlatban megjelenő tartalomhordozókban milyen műveltségterületeken, milyen módokon, milyen vizuális és tartalmi elemeken keresztül történik a cigány/roma kultúra bemutatása. A kutatást a PTE BTK Romológia és Nevelésszociológia Tanszéke végezte. 
A vizsgálat tárgya egy 258 tételes tankönyvlistán megtalálható tartalomhordozók kvantitatív és kvalitatív elemzése volt. Az elemzés célja annak vizsgálata, hogy ezekben a döntően közismereti tankönyvekben, munkafüzetekben, szöveggyüjteményekben megjelenik-e, s ha igen, hogyan reprezentálódik a cigányság, és a közoktatásban tanuló diákoknak nyújtott ismeretek mennyire segítik e csoport társadalmi befogadását.

A kutatási eredmények azt mutatják, hogy a NAT elvárásai szerint a nemzetiségi tartalmaknak megjelenése, valamint e tartalmaknak a kerettantervekben való elöfordulása között nincs teljes összhang minden tantárgy esetében. Ennek eredménye, hogy a vizsgált tankönyvi korpuszok kétharmadában egyáltalán nem jelenik meg semmiféle ismeret a cigányokról/ romákról.

A cigány/roma nemzetiséggel kapcsolatos tartalmak megjelenítése nemcsak a lehetőségek kiaknázásában maradt el a várttól, hanem esetenként félreértelmezhető vagy negatív képet sugall a hazai cigányságról. A tankönyvek vizsgálatának eredményeit öszszegezve azt láttuk, hogy a cigányok/romák reprezentációja az új fejlesztésü tankönyvekben kevésbé hangsúlyos. Ugyanakkor mind pedagógiai, mind tudományos szempontból végiggondolásra ajánlottuk az új tankönyveknek a jogi szabályozók által is elöírt tartalom arányának meghatározását, a tankönyvek struktúrájának, illetve tantárgyanként változó koncepcióinak az átvizsgálását is olyan megvilágításból, amely arra törekszik, hogy az országban élő különböző nemzetiségeket és népcsoportokat „láthatóbbá” tegye a többségi társadalom és a saját nemzetiségi közösségeik számára is.

A jelenlegi tankönyvek kis százalékában található cigány/roma tartalom alapján a cigányokról alkotható kép rendkívül szük keresztmetszetű és korántsem megnyugtató. A cigányokról/romákról - ahogy egyébként a többi hazai nemzetiségről is elmondhatjuk - a vizsgált tankönyvekben csak nagyon kevés pontos és korrekt ismeret található. A cigányok/romák helyzete minden más hazai nemzetiséghez képest azért rosszabb, mert ők gyakran csak a szélsőséges helyzetekben, a perifériákon bukkanhatnak elő.

A cigány/roma közösség a jog szintjén ugyan nemzetiség, de mint nemzetiség, nem indul ugyanarról a kiindulópontról. A hazai nemzetiségek mindegyike mögött ott áll egy anyaország, amely segíti a más országokban élő népcsoportjainak kulturális fennmaradását. A hazai cigányságnak anyaországa nem lévén, ilyen háttér-támogatottsága nincsen, mindemellett aluliskolázottsága és a munkaerőpiaci értéktelensége miatt a szociális és anyagi létbizonytalanság és a kirekesztettség jellemzi hétköznapjait, így a kulturális és nyelvi megmaradás nem tartozik a legégetőbb problémái közé.

A státuszának megegyező oktatás új fordulóponthoz ért. Az eddigi önálló tantárgyi keretben történő nemzetiségi oktatás - minden eddigi problémás megvalósulása ellenére - nagyobb lehetőséget adott információk átadására, mint a most lehetőséget kapott integrálás, amelynek feltételei sem a tankönyvek tananyagtartalmában, sem a romológiai ismeretekkel rendelkező pedagógusokkal nincsenek megtámogatva. Előre megjósolható módon ez a tantárgyi integráció adminisztratív és nem tényleges népismereti oktatást fog eredményezni, ami minden eddiginél nagyobb visszalépést jelent az eddig se magas fokon megvalósuló cigány/roma nemzetiségi népismereti oktatás területén.

Jelen helyzetben utópisztikus elvárásnak tünik, mégis fontos lenne a többi nemzetiség oktatását tanulmányozva, hasonló feltételek mentén előkészíteni és megszervezni a cigány/roma nemzetiségi oktatást. Egyértelművé kell tenni a cigány/roma nemzetiségi népismeret tantárgy jogszabályi megalapozottságát - önálló tantárgyként. Csak olyan intézmény indíthasson cigány/roma nemzetiségi képzést, amelyik megfelelő végzettsé- 
gű pedagógust alkalmaz. Ezzel párhuzamosan meg kellene erősíteni a romani és beás nyelvtanárképzést, biztosítani kellene a megfelelő nyelvkönyveket, valamint az oktatáshoz szükséges személyi és tárgyi feltételeket, és hosszú távon a magyar nyelvü cigány/ roma nemzetiségi nevelés-oktatás formát megszüntetve a képzés kötelező elemévé kellene tenni az anyanyelv tanulását.

\section{IRODALOM}

Arató F. \& Varga A. (2005) A kooperativ hálózat müködése. Pécs, PTE BTK NTI Romológia és Nevelésszociológia Tanszék.

Balázsi I., Lak Á. R., Szabó V. \& Vadász Cs. (20I3) Országos kompetenciamérés 2012. Országos jelentés. Budapest, Oktatási Hivatal.

FóriKa L. (2013) A cigány tanulók elkülönítése a köznevelés rendszerében. In: Hajas B. \& Szabó M. (eds) Pajzsuk a törvény. Budapest, Alapvető Jogok Biztosának Hivatala. pp. 99-132.

FórIKa L. Dr. (2015) A cigány nemzetiségi oktatás helyzete a nemzetiségi oktatás rendszerében az ombudsmani jelentések tükrében. Romológia, Vol. 3. No. 9. pp. 2-21.

Forray R. K. (1995, ed.) Publikációk a cigányság oktatásáról. Budapest, Oktatáskutató Intézet. Kutatás közben.

Forray R. K. (1998) Nemzetiségek, kisebbségek. Educatio, Vol. 7. No. 1. pp. 50-66.

Forray R. K. \& Hegedüs T. A. (1990) A cigány etnikum újjászületöben. Tanulmány a családról és az iskoláról. Közoktatási Kutatások. Budapest, Akadémiai Kiadó. pp. 25-31.

Forray R. K. \& Hegedüs T. A. (1995) Oktatáspolitikai változások a cigány gyerekek iskoláztatásában. Iskolakultúra, Vol. 5. No. 24. pp. 7-18.

Forray R. K. \& Hegedűs T. A. (1998) Cigány gyermekek szocializációja. Budapest, AULA.

HajnÁCZky T. (2013) Az 1961-es párthatározat margójára. Dokumentumok az MSZMP KB PB 1961. június 20-án kiadott határozatának Borsod-Aba-új-Zemplén megyei végrehajtásáról. Múltunk, No. 1. pp. 237-272.

HajNÁczky T. (2015) A pártállam cigánypolitikája. Esély, 2015/5. http://www.esely.org/ kiadvanyok/2015_5/2015-5_2-1_Hajnaczky_Partallam_ciganypolitikaja.pdf [Letöltve: 2020. 11. 29.]

HajNÁCZKy T. (2015, ed.) „Egyértelmü, hogy a cigányok nem tekinthetöek nemzetiségnek." Cigánypolitika dokumentumokban 1956-1989. Budapest, Gondolat Kiadó.

Kaltenвасн J. (2003) A nemzeti és etnikai kisebbségi jogok országgyülési biztosának jelentése a 2002. és 2003. évi kisebbségi önkormányzati választásokról. https://adattar.adatbank. transindex.ro/Magyarorszag [Letöltve: 2020. 11. 29.]

Kertesi G. (1995) Cigány gyerekek az iskolában, cigány felnőttek a munkaerőpiacon. Közgazdasági Szemle, Vol. 1.pp. 30-65.

Kertesi G. \& Kézdi G. (2010) Iskolázatlan szülők gyermekei és a roma fiatalok a középiskolában. Beszámoló az Educatio Életpálya-felvételének 2006 és 2009 közötti hullámaiból. Közgazdasági Szemle, Vol. 59. pp. 7-8.

Orsós A. (2015) Cigány/roma nemzetiségi oktatás. Kutatási beszámoló. Pécs, Wlislocki Henrik Szakkollégium, PTE BTK NTI Romológia és Nevelésszociológia Tanszék.

RÉGER Z. (1995) Cigány gyerekek nyelvi problémái és iskolai esélyei. Iskolakultúra, Vol. 5. No. 24. pp. 102-106.

Szuhay P. (1999) A magyarországi cigányok kultúrája: etnikus kultúra vagy a szegénység kultúrája. Budapest, Panoráma. 
SzüDI J. (1996) Közoktatás-igazgatás. Budapest, OKKER.

\section{INTERNETES FORRÁSOK}

1990. évi LXV. törvény a helyi önkormányzatokról. https://mkogy.jogtar.hu/ jogszabaly?docid=99000065.TV

1993. évi LXXVII. törvény a nemzeti és etnikai kisebbségek jogairól. https://mkogy.jogtar. hu/jogszabaly?docid=99300077.TV

2011. évi CLXXIX. törvény a nemzetiségek jogairól. https://mkogy.jogtar.hu/ jogszabaly?docid=a1100179.TV [Letöltve: 2020. 08. 29.]

2011. évi CLXXIX. törvény - a nemzetiségek jogairól. https://net.jogtar.hu/ jogszabaly?docid=a1100179.tv [Letöltve: 2020. 08. 29.]

2011. évi CXC. törvény - a nemzeti köznevelésről. https://mkogy.jogtar.hu/ jogszabaly?docid=a1100190.TV [Letöltve: 2020. 08. 29.]

2011. évi CXC. törvény A nemzeti köznevelésről. http://www.kozlonyok.hu/nkonline/ $\mathrm{mkpdf} /$ hiteles/mk11162.pdf [Letöltve: 2020. 11. 29.]

17/2013. (III. 1.) EMMI rendelet - a nemzetiség óvodai nevelésének és a nemzetiségi iskolai oktatásának irányelve kiadásáról. https://net.jogtar.hu/jogszabaly?docid=A1300017. EMM\&timeshift $=20170831 \&$ txtreferer $=00000003$.TXT [Letöltve: 2020. 08. 29.]

Jelentés (2011) Jelentés a nemzeti és etnikai kisebbségi általános iskolai nevelés-oktatás helyzetéről. Nemzeti és etnikai kisebbségi jogok országgyülési biztosa. http://www. kisebbsegiombudsman.hu/data/files/217986220.pdf [Letöltve: 2020. 08. 29.]

A nemzetiségi nevelés-oktatás kerettantervei - Kerettantervek. http://kerettanterv.ofi. hu/10_melleklet_nemzetisegi/index_nemzetisegi.html [Letöltve: 2020. 08. 29.]

MNTF Stratégia (2011) Magyar Nemzeti Társadalmi Felzárkózási Stratégia II. Tartósan rászorulók-szegény családban élő gyermekek-romák (2011-2020) (2014): Frissített változat, Budapest, EMMI, Szociális és Társadalmi Felzárkózásért Felelős Államtitkárság. https://www.kormany.hu/download/1/9c/20000/Magyar\%20NTFS\%20II\%20_2\%20 mell\%20_NTFS\%20II.pdf [Letöltve: 2020. 08. 29.]

Nemzetiségi irányelvek - 31/2020. (VIII. 31.) A nemzetiség óvodai nevelésének és a nemzetiség iskolai nevelés-oktatásának irányelve. https://www.oktatas.hu/kozneveles/ kerettantervek/2020_nat/iranyelvek_nemzetisegi_oktatashoz [Letöltve: 2020. 11.29.]

A cikk a Creative Commons Attribution 4.0 International License (https://creativecommons.org/licenses/ by/4.0/) feltételei szerint publikált Open Access közlemény, melynek szellemében a cikk bármilyen médiumban szabadon felhasználható, megosztható és újraközölhető, feltéve, hogy az eredeti szerző és a közlés helye, illetve a CC License linkje és az esetlegesen végrehajtott módosítások feltüntetésre kerülnek. (SID_1) 